\title{
A REPÜLÉSIRÁNYÍTÓK TELJESÍTŐKÉPESSÉGÉNEK ÉS SZAKMAI ATTITÜDJÉNEK VIZSGÁLATI TAPASZTALATA PSZICHO-FIZIOLÓGIA MÉRÉSI EREDMÉNYEK ALAPJÁN
}

DOI: $10.32560 / \mathrm{rk} .2019 .1 .3$

A légiközlekedés technológiai fejlödése miatt az ember kezd háttérbe szorulni, azonban a repülöesemények jelentös része manapság is humán területre vezethetö vissza. Kétségtelen tehát, hogy a nagyobb biztonság eléréséhez az emberi tevékenység folyamatos vizsgálata és a hibázás kialakulásának csökkentése vezet. A hibázás megjelenésének oka legtöbb esetben a munkahelyi stressz helytelen kezelése, vagy annak elmulasztása. A repülésben részt vevő személyeknek a Katonai Repülö Intézetben folyó kutatás által lehetősége van egyéni stressz állapot méréseken részt venni, mellyel átfogó képet kapnak életmódjuk minöségéről és megismerik szervezetük reakcióit a szolgálatban eltöltött idö alatt bekövetkezö eseményekre. A cikk a testszenzoros mérési eredmények és a vizsgálatban részt vevők szubjektiv véleményének összehasonlitó elemzését mutatja be.

Kulcsszavak: emberi tényezö, repülésirányitás, teljesitőképesség, stressz állapot, regenerálódás

\section{BEVEZETÉS}

A repülésbiztonság humán aspektusainak vizsgálata a repülés humán tényezőinek integrált alkalmazására fókuszál, melyek a pilóták mellett a pilótanélküli légijármüvek kezelőire és a repülésirányítókra is kiterjednek. Egyik meghatározó eleme a katonai repülésirányítók funkcionális állapotának vizsgálata különböző élethelyzetekben. A kutatás magába foglalja az adatgyüjtést és elemzést, új mérési és vizsgálati módszerek tesztelését, valamint a gyakorlati alkalmazás eredményeinek összesítését és a mindennapokban zajló alkalmazási lehetőségének kialakítását [1][2].

A funkcionális állapotvizsgálat egyik részfeladata a repülésirányítók stressz állapotának vizsgálata. A stressz állapot mérésére több vizsgálati módszer is rendelkezésre áll, melynek oka, hogy a stressz emberi szervezetre gyakorolt hatása különböző szinteken jelentkezik, amely az alábbi eljárások segítségével tehető mérhetővé:

1. Az egyik lehetséges módszer a jelentkező tünetek megadott szempontrendszer szerint történő megfigyelése, monitorozása. A módszer hátránya, hogy időigényes és jelentős emberi erőforrást igényel.

2. Egy következő eljárás az úgynevezett „nem beavatkozó” jellegü módszer, amely a stressz hatás következtében létrejövő, a stresszel bizonyítottan összefüggő megbetegedési-, baleseti- vagy hiányzási mutatók elemzését foglalja magában. Az eljárás jó következtetési alapot nyújthat, azonban az egyén stressz állapot méréséhez csak általános adatokkal szolgál.

3. A harmadik potenciális vizsgálati irány az önbevalláson alapuló kérdőíves módszer. Az eljárás során az egyén stressz tüneteinek jelenlétére és annak mértékére kérdeznek rá. A

\footnotetext{
${ }^{1}$ Olyan események, melyek a légiközlekedés biztonságát befolyásolják.
} 
vizsgálat hátránya a szubjektivitás, amelynek következtében az nem ad valós képet az alany állapotáról.

4. Végül, a pontosabb diagnosztika felállításának érdekében alkalmazhatók az eszközvizsgálatos eljárások, melyek pillanatnyi és hosszú távú stressz állapot rögzítésére is alkalmasak [3].

A kutatás során az önbevalláson alapuló kérdöíves módszer és az eszközvizsgálatos módszer alkalmazásával kapott eredményeket dolgoztam fel. Mindez részeredményként szolgál az intézetben folyó kutatási projekt eredményeihez.

\section{Önbevalláson alapuló kérdőíves módszer}

Ez a vizsgálati módszer szubjektív, a vizsgált egyén észlelésén alapul, ezért nem ad valós eredményt, mégis ez az egyik leggyakrabban előforduló módja a stressz állapot mérésnek. A következőkben a kutatási projekt keretein belül előállított kérdőívet mutatom be.

Az általam összeállított kérdőív 21 tételből áll, amely a főbb munkahelyi stresszorok ${ }^{2}$ és a fizikai aktivitás jelenlétét méri. Ezek a következők:

$\rightarrow$ munkakapcsolatok;

$\rightarrow$ munkakörnyezet;

$\uparrow$ elismerés, megbecsülés;

$\rightarrow$ munkahelyi szerep;

$\rightarrow$ felelősségvállalás;

$\rightarrow$ fizikai aktivitás.

A kérdöívben ötfokozatú gyakorisági skálát alkalmaztam, melyek az állítások mellett találhatók. A teszt alkalmazásának előnye, hogy a későbbiekben bemutatásra kerülő eszközvizsgálatos állapotfelmérés eredményeivel összevethető szubjektív véleményekkel is rendelkezünk.

1. Tisztában vagyok a szolgálati kötelességemmel és felelősségemmel.

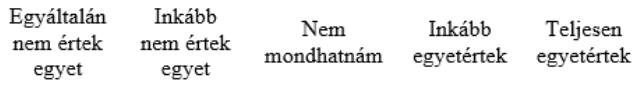

2. Szolgálati tevékenységem során összeszedett vagyok.

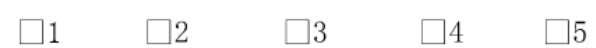

3. Szolgálatban kiegyensúlyozott a kollégák közötti viszony.

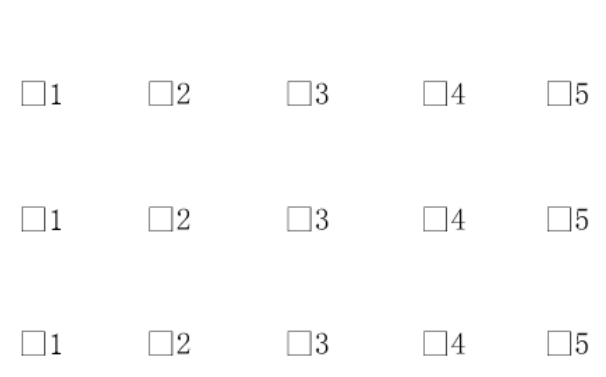

4. Számíthatok a felettesem segítségére, ha problémába ütközöm munkám során.

1. ábra A stressz állapot felmérő kérdőív részlete

\section{Eszközvizsgálatos módszer}

A pontosabb eredmény érdekében célszerübb az egyéneket hosszú távú mérési folyamatba bevonni, amelyek megvalósítására a legnagyobb elektronikai fejlesztő cégek olyan hordozható eszközöket alkottak meg, melyek életvitel szerủen monitorozzák a használókat. Például egy

\footnotetext{
${ }^{2}$ A stresszt előidéző tényezők Selye János magyarázata szerint
} 
okosórába épített pulzusszám mérő vagy lépésszám mérő alkalmazás megőrzi az adatokat a memóriájában és egy trend olvasható ki az alany életmódjában.

A stressz állapot mérésére kifejlesztett hordozható eszközök között a piacvezető vállalat a finn FirstBeat Technologies, amely közel két évtizede foglalkozik az emberi szervezetre ható terhelések és reakció képességek korrelációjának kutatásával. Az általa létrehozott FirstBeat BodyGuard 2 termék technológiai alapja a szívfrekvencia változékonyság $\left(\mathrm{HRV}^{3}\right)$, azaz a pulzusvariancia mérése.

A korábban említett kutatás lehetővé teszi a repülésirányítók hosszú távú stressz kitettségének vizsgálatát a FirstBeat mérőműszer segítségével.

A készülék használatával a vizsgált személy a következő tényezőkről kap objektív visszajelzést:

$\rightarrow$ a mindennapi tevékenységek alatti stresszterhelésről;

$\neg$ a pihenés alatti feltöltődés mértékéről és minőségéről;

$\rightarrow$ a fizikai aktivitás állapotáról;

$\rightarrow$ az alvásminőségről;

$\dashv$ és az energiaháztartás egyensúlyáról [4].

A mérést követően a FirstBeat program elkészíti a riportot, amely alapján elemezhetők a felsorolt tényezők. Felismerhetővé válnak a stresszt okozó tevékenységek és helyzetek, és a szakértők megoldást javasolnak az életminőség vagy a munkateljesítmény javítására.

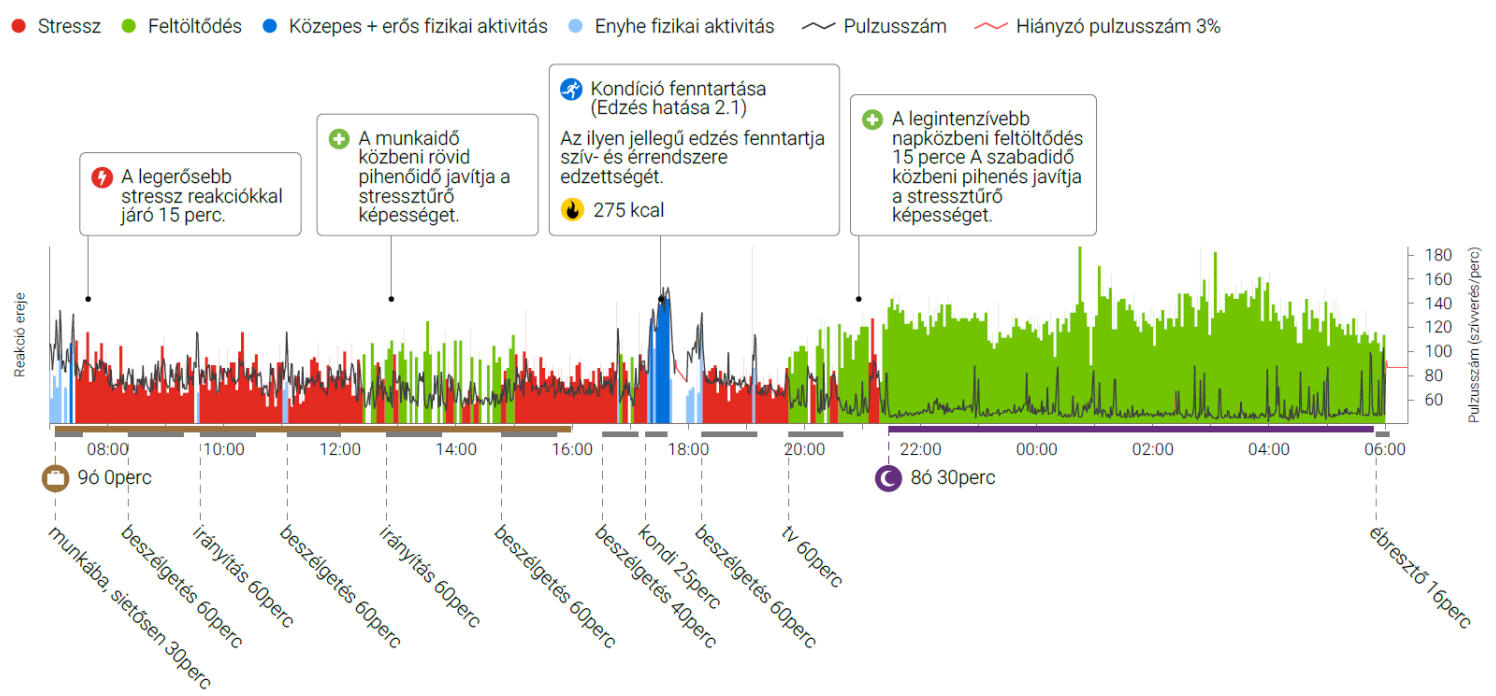

2. ábra Egy, a kutatásban részt vevő repülésirányító 24 órás mérési profilja [5]

\section{A TELJESÍTŐKÉPESSÉG VIZSGÁLATA}

A vizsgálat célja az volt, hogy tanulmányozzam a repülésirányítók szolgálata során adott stressz reakcióinak mértékét és az ezt követő regenerálódás minőségét. A vizsgált személyek közül 18 aktív repülésirányító mérési eredményeit és stressz állapotáról adott szubjektív véleményeit ismertetem. A részt vevők különleges adatainak minősülő egészségügyi jellemzőit a GDPR ${ }^{4}$ irányelveknek megfelelően kezeltem.

\footnotetext{
${ }^{3}$ Heart Rate Variability. Az egyes szívizom összehúzódások között eltelt idő századmásodpercben.

${ }^{4}$ General Data Protection Regulation. Általános Adatvédelmi Rendelet
} 
Az egyéni riportokból minden 24 órás mérési periódus végén a következő adatok olvashatók ki:

$\rightarrow$ Stresszre adott reakciók mennyisége;

$\uparrow$ Pihenés mennyisége;

$\neg$ Stressz és feltöltődés egyensúlya;

$\uparrow$ Feltöltődés mennyisége alvás alatt;

$\downarrow$ A feltöltődés minősége (pulzusvariancia);

$\rightarrow$ Alvás regenerációs hatása;

$\rightarrow$ Fizikai aktivitás;

$\uparrow$ és összes energiafogyasztás.

Az egyének felsorolt szempontok szerinti eredményeit egy táblázatban összesítettem, az adatokból csoportos grafikonokat készítettem, melyeket az alábbiakban szemléltetek [5].

\section{Stresszre adott reakciók mennyisége}

A stresszre adott reakciók mennyisége az az adat, amely megmutatja az egyén 24 óra alatti stressz kitettségét százalékos arányban. Ha ez a mutató legfeljebb 60\%-os, „,normális”, ha meghaladja azt, akkor „a szokásosnál több” a stresszre adott reakciók száma.

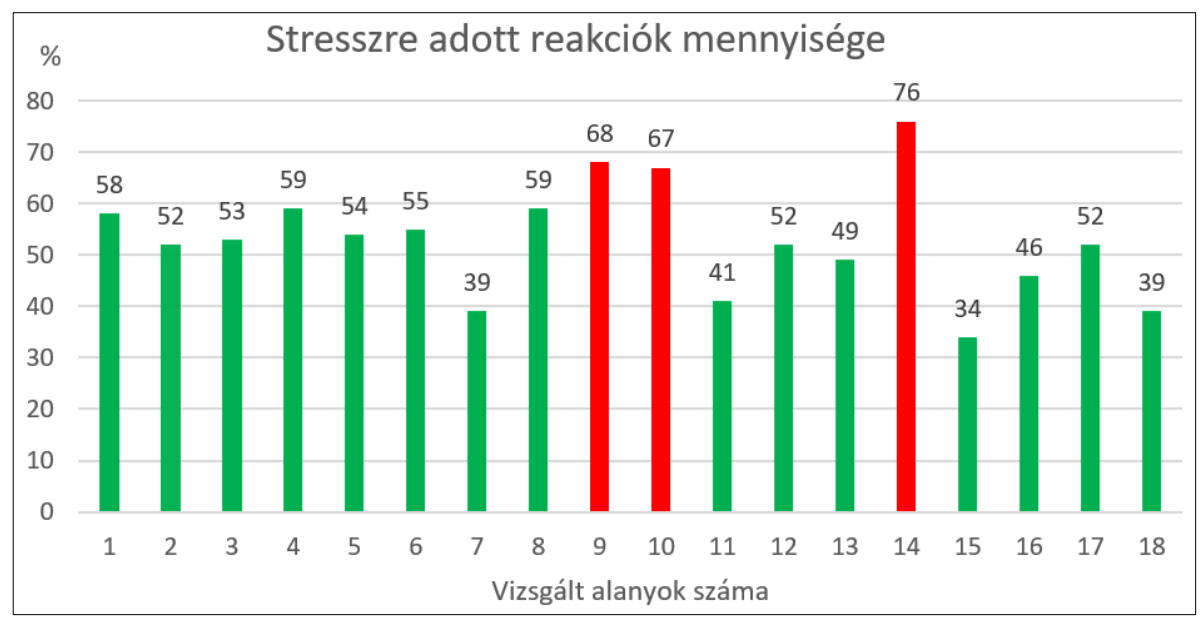

3. ábra Stresszre adott reakciók mennyisége (szerkesztette a szerző) [5]

A vizsgált repülésirányítók stresszre adott reakciók mennyiségének átlaga 52,94\%, amely csoport szinten a „normális” szintet jelenti. A diagrammból kiolvasható, hogy három alany meghaladta a $60 \%$-os értéket.

Az eredmények összehasonlításához a kérdőívben szereplő állítások közül az „Általában nem érzem magam stresszesnek" állítás bizonyul a legalkalmasabbnak. A kitöltők 28\%-a (5 fö) „,nem mondhatnám”, 39\%-a (7 fö) „inkább egyetértek” és 33\%-a (6 fơ) „teljesen egyetértek” választ adott. Ennélfogva a repülésirányítók 72\%-a nem gondolja, hogy munkája során nagy stressz hatásnak van kitéve. A szubjektív válaszok tükrözik a FirstBeat eszközzel végrehajtott mérési eredményeket, ugyanis csupán három alany haladta meg a 60\%-os értéket. [5]

\section{Pihenés mennyisége}

A pihenés mennyisége azt mutatja meg, hogy a vizsgált személy a mérési időszak során hány százalékot töltött pihenéssel. Ha a kimutatott mennyiség 20\% alatti, akkor „gyenge”, ha 20\% és 29\% közötti, akkor „közepes”, és ha meghaladja a 30\%-ot, akkor ,jó” értékelést kapott az alany. 


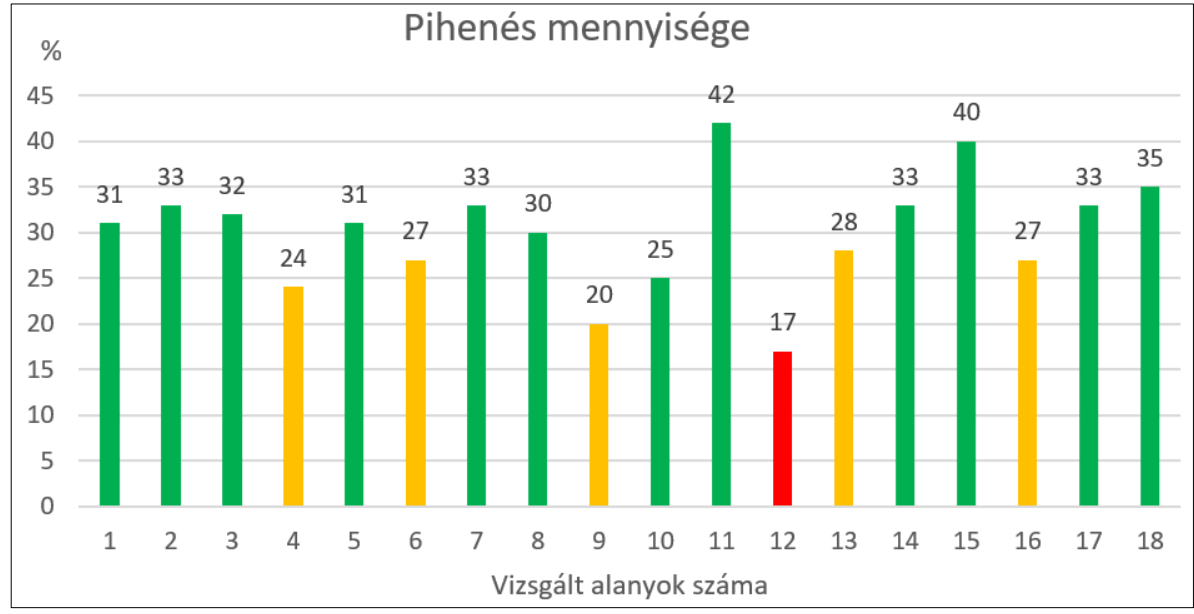

4. ábra Pihenés mennyisége (szerkesztette a szerző) [5]

A pihenés mennyiségét ábrázoló diagrammon látható, hogy tizenkét repülésirányító elegendő mennyiségü pihenéssel zárta a vizsgált napot, és három alany $20 \%$ és $29 \%$ közötti értéket produkált. A csoport átlaga 30,05\%, ami eléri a ,jó" értékelés alsó szintjét.

Ennek az adatnak a kimutatására a legmegfelelöbb állítás: „A napjaim (szolgálatban) többnyire tartalmaznak olyan szüneteket, amelyekben kissé kipihenhetem magam”. A kitöltők válaszai a következők voltak:

$\rightarrow 6 \%$ (1 fö) ,inkább nem értek egyet”;

$\rightarrow$ 28\% (5 fö) „,nem mondhatnám”;

† 39\% (7 fö), ,inkább egyetértek";

$\rightarrow 28 \%$ (5 fö) ,teljesen egyetértek”.

A korábbi eszközvizsgálatos mérési eredmények nagy szórását a repülésirányítók szubjektív véleménye is megerősíti. A válaszok alapján a vizsgált csoport többségének, 67\%-nak lehetősége van napközbeni pihenöket beiktatni munkavégzés során. [5]

\section{Feltöltődés mennyisége alvás alatt}

Ez az érték megmutatja, hogy az alany alvási időszakának hány százalékát töltötte tényleges feltöltődéssel. A program kiértékelése szerint itt is három kategóriába kell az eredményeket sorolni:

$\rightarrow$ kevesebb, mint $50 \%$ gyenge;

$\rightarrow 50 \%$ és $74 \%$ között közepes;

† 75\% felett jó a feltöltődés szintje.

A csoport alvás alatti feltöltődésének átlaga 82,66\%, amely ,jó” értéknek számít. Tizenkét alany ért el a csoport átlagánál magasabb regenerálódási szintet.

A kitöltők számára az „Úgy érzem, hogy eleget alszom” állítás bizonyult a legmegosztóbbnak. $6 \%$ egyáltalán nem ért egyet, $11 \%$ inkább nem ért egyet, $33 \%$ nem mondhatná, $44 \%$ inkább egyetért és csupán $6 \%$ ért egyet teljes mértékben azzal, hogy a 24 óra során eleget alszik. A kérdőív alapján a csoport 17\%-a úgy gondolja, hogy nem elegendő az éjszakai feltöltődésének mennyisége, 33\%-a gondolja közepes szintünek és 50\%-a tapasztalja megfelelőnek a feltöltődését. A szubjektív véleményekkel ellentétben a testszenzoros mérési eredmények kimutatták, hogy a vizsgált repülésirányítók 72\%-ának ,jó” a feltöltődés mennyisége alvás alatt [5]. 


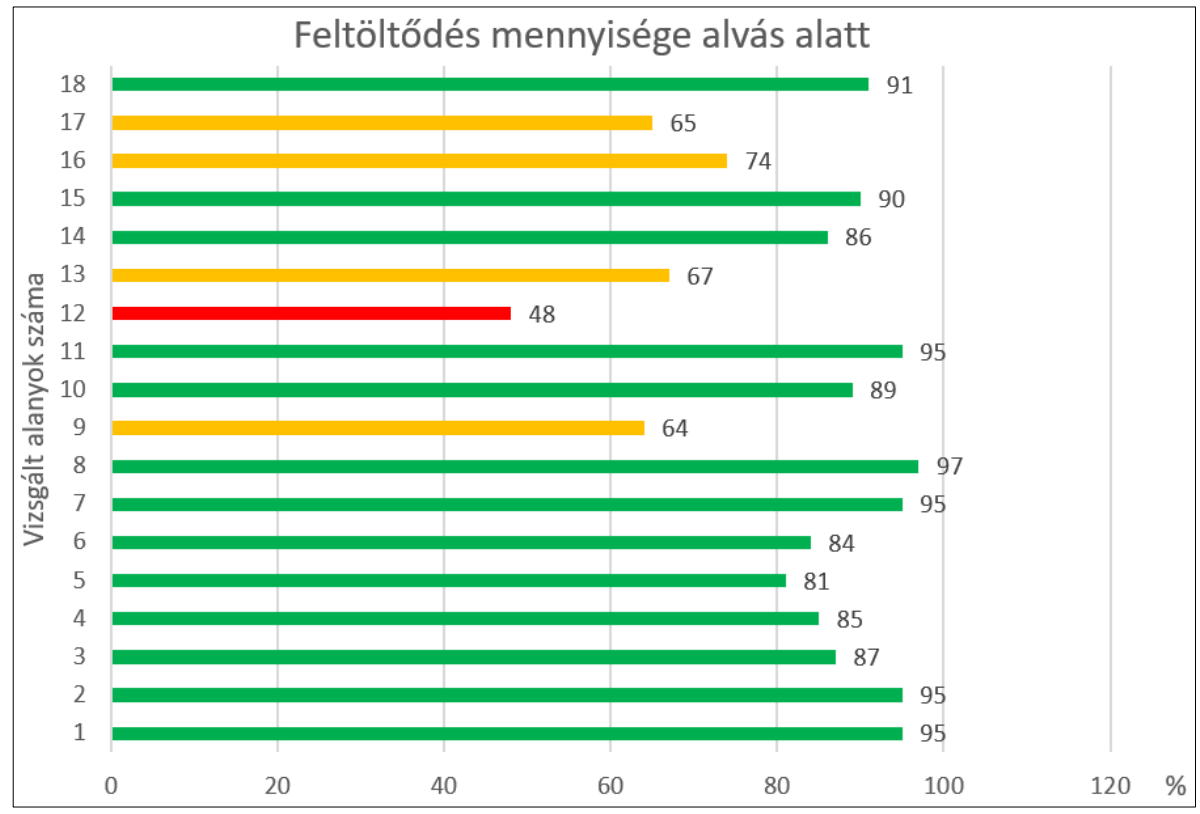

5. ábra Feltöltődés mennyisége alvás alatt (szerkesztette a szerző) [5]

\section{Alvás regenerációs hatása}

Az alvás regenerációs hatása az alvás időtartamától, valamint az alvás alatti pihenés mennyiségétől és minőségétől függ. Az egyik legfontosabb mutató, hiszen ebből derül ki, hogy a szervezet mennyire képes feltöltődni a napközbeni stressz kitettség után, illetve, hogy milyen mértékben tud visszatöltődni a következő napi stressz elött.

A grafikon tökéletesen illusztrálja, hogy a vizsgálati csoportban három fő is képes volt a 100\%os regenerálódásra, a 2. számú alany pedig közel tökéletes, 98\%-os eredményt ért el. Négy repülésirányítót jellemez 30\% és 59\% közötti érték, amely „,közepes” regenerálódási képességet jelent. Megfigyelhető, hogy egyik alany sem került 29\%-os érték alá, ami a „gyenge” regenerációt jelentené.

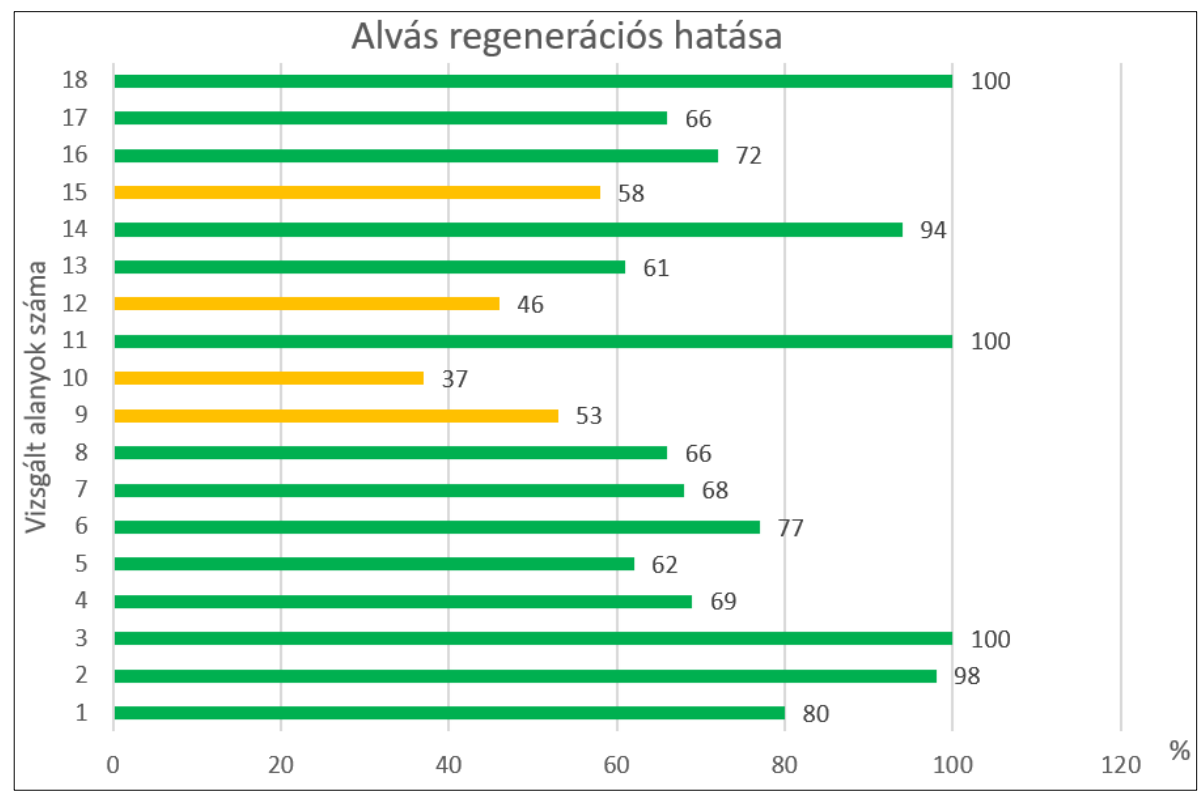

6. ábra Alvás regenerációs hatása (szerkesztette a szerző) [5] 
Ez a mutató az „Általában kipihentnek és energikusnak érzem magam ” állítással vonható párhuzamba. A válaszadók 39\%-a (7 fö) nem mondhatná, 50\%-a (9 fö) inkább egyetért és 11\%-a (2 fö) teljes mértékben egyetért azzal, hogy kipihent és energikus. Látható, hogy erre az állításra adott válaszok szintén egybevágnak a FirstBeat eszközzel mért objektív eredményekkel [5].

\section{ÖSSZEGZÉS}

Tanulmányomban a repülésirányítók stressz állapotának vizsgálati tapasztalatát átfogó és komplex módon mutattam be két módszer alkalmazásával. A vizsgálat célja az volt, hogy tanulmányozzam a repülésirányítók szolgálata során kialakult stressz és regenerálódás egyensúlyát, valamint, hogy megismerjem a vizsgált személyek szubjektív véleményét saját stressz állapotukról.

A kutatás során világossá vált számomra, hogy a mérési eredmények és a kérdőív egyes állításaira adott válaszok többnyire egybevágnak, azaz a vizsgált repülésirányítók hasonlóan vélekednek saját stressz állapotukról, mint amit objektív módon a testszenzor mutatott ki a mérések alkalmával.

A humán tényező nemcsak a repülési rendszer egészének része, hanem a repülésbiztonság egyik alapvető eleme is. A repülésben részt vevő személyek, így a repülésirányítók célja a maximális teljesítményre való törekvés a repülőesemények elkerülésének érdekében, amely a repülésbiztonság alapvető feladata.

\section{FELHASZNÁLT IRODALOM}

[1] repulestudomany.hu, „Aviation Human kiemelt kutatási terület” [Online]. Elérhetö: http://kutatas.repulestudomany.hu/elemek/aviation_human.html

[2] Bottyán Zsolt - Dunai Pál - Fekete Csaba - Gajdos Máté - Palik Mátyás - Sápi Lajos - Vas Tímea: A repülésirányítás alapjai. Nemzeti Közszolgálati Egyetem. Nordex Nonprofit Kft. - Dialóg Campus Kiadó. 2016. ISBN 978-615-5889-44-8

[3] ommf.gov.hu, „Útmutató a munkahelyi stressz kezeléséhez munkavédelmi szakemberek részére”. www.ommf.gov.hu/letoltes.php?d_id=5577. Letöltés: 2018.10.13.

[4] fusionvital.hu, ,Életmód felmérés” [Online]. Elérhető: http://fusionvital.hu/megoldasaink/fusion-vital/.

[5] Molnár Bernadett: Stressz management lehetősége az állapotvizsgálat korszerú módszereivel a repülésirányítás területén és ennek jelentősége a repülésbiztonság növelésében. Szakdolgozat. 2019. Nemzeti Közszolgálati Egyetem

\section{THE RESEARCH EXPERIENCE OF MILITARY AEROSPACE CONTROLLERS' PERFORMANCE AND PROFESSIONAL ATTITUDE BASED ON PSYCHO-PHYSIOLOGY MEASUREMENT RESULTS}

Over the last decades the technology uses in aviation has grown at an exceptionally high rate, resulting that more and more functions have being taken over by machines, but the presence of humans is still the most common cause of an aircraft incident nowadays. For reaching a higher safety the most important factors are the continuous investigation of human activity and the reducing of human error. For the persons involved in aviation have the opportunity to take part in stress status measurements within the research project in Institution of Military Aviation, to get a complex picture of the quality of their lifestyle and to get to know their reactions of events during their duty. In the paper a comparative analysis of body sensor measurement results and the subjective opinion of the participants are presented.

Keywords: human factor, aerospace controlling, performance, stress status, regeneration 


\begin{tabular}{ll}
\hline Molnár Bernadett & Bernadett Molnár \\
Hallgató & Student \\
Nemzeti Közszolgálati Egyetem & National University of Public Service \\
Hadtudományi és Honvédtisztképzö Kar & Faculty of Military Science and Officer Training \\
Katonai Repülö Intézet & Institute of Military Aviation \\
Repülésirányító és Repülö-hajózó Tanszék & Department of Aerospace Controller and Pilot Training \\
molnarbernadett1995@gmail.com & molnarbernadett1995@ gmail.com \\
orcid.org/0000-0001-7791-4159 & orcid.org/0000-0001-7791-4159 \\
\hline
\end{tabular}

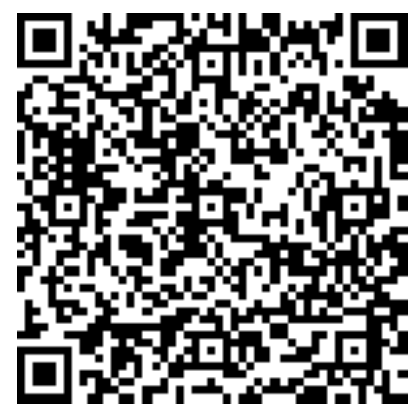

http://journals.uni-nke.hu/index.php/reptudkoz/article/view/318/32 